\title{
Border-landscape Changes. The Case of Slovenia
}

\author{
Jernej ZuPANČIČ, Ljubljana*
}

\section{Content}

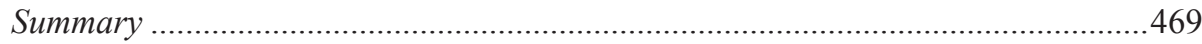

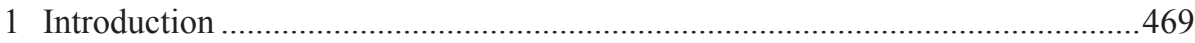

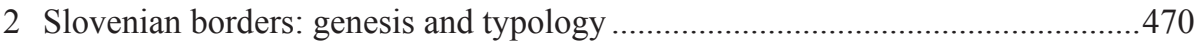

3 Minorities as impact factors in borderlands ....................................................4 473

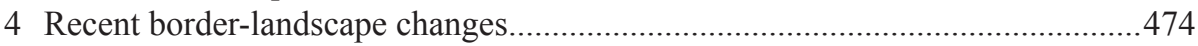



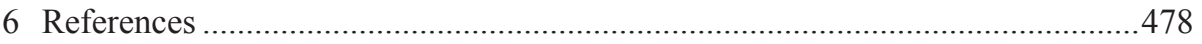

\section{Summary}

The paper is analysing contemporary processes in Slovenian border areas. Due to different political situations in the near past, at Slovenia's various border sections emerged various types of borderlands: co-operative and structurally asymetric at the western and northern borders of Slovenia, limited co-operation and symetric in the East. The border with Croatia is the youngest and therefore still accomodating to the new situation. The paper focuses on cross-border co-operation and the role of ethnic minorities in this context.

\section{Introduction}

Border areas are a special type of cultural landscape influenced by local characteristics as well as by hinterland and international factors. Ethnic minorities play a

* Jernej Zupančıč, PhD., Associate Professor, Department of Geography, Faculty of Arts, University of Ljubljana, Aškerčeva 2, SI-1000 Ljubljana, Slovenia, e-mail: jernej.zupancic@ff.uni-lj.si 
special role there having undergone various positions, from being exposed to genocidal policies to the role of 'bridge-makers'. Structural characteristics of border areas are crucial factors for their position.

Positioned in the southern part of Central Europe, Slovenia is a true border country. Due to its relativelly small size $\left(20,273 \mathrm{~km}^{2}\right)$, more than half of its territory is part of a 25-kilometers border belt. Slovenia is bordering Italy, Austria, Hungary and Croatia. The total border length is $1,334 \mathrm{~km}-17 \%$ with Italy, $25 \%$ with Austria and $8 \%$ with Hungary, while almost exactely half of Slovenia's land border connects it with Croatia: $670 \mathrm{~km}$ (FRIDL et al. 2001, p. 14). Slovenia's character of a border country is also confirmed by the proportion between international borders and state surface. According to this indicator, Slovenia is second among European countries with $5.7 \mathrm{~km}$ border length per $100 \mathrm{~km}^{2}$ (BufON 2004, p. 23). The Slovenian maritime border (towards Italian and Croatian territorial waters in the Upper Adriatic shelf sea) is still (in 2015) under dispute, a decision is to be felt by the International Arbitrary Court during the next years. ${ }^{1}$

This contribution examines three border sections, i.e. the Slovenian-Italian (Gorizia - Nova Gorica), the Austrian-Slovenian (Bad Radkersburg - Gornja Radgona) and the Slovenian-Hungarian as well as, with some special remarks, the Slovenian-Croatian. Based on a comparative analysis of the border-area structure, the effects of motherland and minority policies, the activities of minorities as well as the main processes in the border areas are outlined by means of five indicators monitored, namely political climate, spatial paradigms, socio-economic development, protection of minorities and activities of persons belonging to minorities.

\section{Slovenian borders: genesis and typology}

It was after World Wars I and II and the collapse of Yugoslavia in 1991 that Slovenia's current boundaries were shaped. The border with Italy was drawn between 1945 and 1954 and fully accepted in 1975 by the Treaty of Osimo (KLEMENČIČ 1987, p. 59). The border with Austria was agreed upon by the Saint Germain Peace Treaty in 1919, a year later the border with Hungary by the Treaty of Trianon (CELAR 2002, pp. 88-90). The border with Croatia was established by the proclamations of independence and by mutual recognition of the two countries in June 1991. However, there are still some border issues on land and at sea between the two countries. A significant milestone was Slovenia's and Hungary's accession to the European Union (EU) in 2004 and later to the Schengen area (2007), when military, police and customs control at the border have been abolished.

1 Slovenia and Croatia agreed in 2012 to delegate the boundary decision (maritime and terrestrial) to the International Arbitrary Court. 
Borderland structures dynamically reflected general modernisation processes and were also influenced by the motherlands of minorities. The borderlands examined here belong to three different types, i.e. cohesive, passive and isolated borderlands.

The Slovenian-Italian border stretches across the foothills of the the Karst Plateau [Kras/Carso] and the Friulian Plain [Pianura friulana]. Whereas some sections respect 'natural boundaries', others dissect densely populated and economically active areas. In longitudinal direction, it extends from the southern Alps through the densely populated areas of the Friulian Plain and the Vipava Valley [Vipavska dolina] to Istria [Istra/Istria]. Old political boundaries between the Habsburg Monarchy and the Venetian Republic and its successor, the Kingdom of Italy, were left slightly to the West. Therefore, the area was for centuries characterised by intensive cultural and economic contact. The new centre of the Slovenian borderland, Nova Gorica, was established directly at the border, demonstrating the defiant nature of these decisions. The areas on both sides of the border are complementary requiring cross-border cooperation and resulting in mutual dependence. Thus, this border section represents the type of cohesive border. The Slovenian minority in Italy is an essential factor in increasing cohesiveness. Due to family ties and friendships, the local population has a lot of personal motives for cross-border co-operation. Moreover, the $10^{\text {th }}$ European transport corridor crosses the Gorica region.

The Slovenian-Austrian border is - in the light of cross-border relations a particular case. In the western part it runs along the mountainous area of the Karavanke/Karawanken, one of the mountain systems in the Southern Alps. The old provincial boundary (between Carinthia [Kärnten] and Carniola [Kranjska], besides Styria [Steiermark] the lands of the so-called Inner Austria of the Habsburg Monarchy) became with a few changes and after military conflict and a plebiscite in 1920 the border between Austria and the State of the Serbs, Croats and Slovenes [Država Srba, Hrvata i Slovenaca, SHS], the predecessor of the Kingdom of Yugoslavia and later the Yugoslav Socialist Federation, where Slovenia took part as a federal unit. It is probably less known that this mountain range was among the most military fortified frontiers in Europe during the interwar period. But recently, exchange and cooperation between Slovenia and Austria (here the Land Carinthia) is very intensive in various fields. This might be because of the presence of the Slovenian minority in Carinthia and extensive and diversified economic cooperation from the 19th century onwards, including the development of industry and mining in Karavanke mountains and on its fringes. This all is likely to contribute to today's lively exchange and a number of cross-border initiatives (ZuPANČIČ 1999a, pp. 339-340). This part is - despite its mountainous character - the most cooperative part of the Slovenian-Austrian border. Together with the Val Canale in Italy, it has proposed the ambitious project of Trilateral Winter Olympic Games (Italy-Austria-Slovenia) for 2006 (MoRITsCH 1999, p. 199). 
Although the initiative did not receive international support, the pioneering spirit of cross-border cooperation remains.

The Slovenian-Austrian border in the section Bad Radkersburg - Gornja Radgona is an example of a passive border. Socio-economic structure on both sides of the border is quite similar. The broad plains along the Mura River represent the central part of the section, and densely populated hills dominate in the background. The area has rather agrarian character with two smaller centres, i.e. Bad Radkersburg and Gornja Radgona, both nestled directly along the border. As the areas are self-sufficient, cross-border communication was limited for decades. The border follows exclusively watercourses, i.e. the Mura River, which was fortified with embankment in order to maintain the flow, and the smaller river Kučnice, the flow of which was adjusted to the agreed border. A negative attitude to minorities prevailed on both sides. While the German population of the Apaško polje was expelled, the Slovenian minority on the Austrian side remained practically ignored for decades (ZuPANČı̌ 1999b, p. 96).

The border between Slovenia and Hungary represents the type of an isolation border. The border is drawn across ethnically homogeneous and entirely agrarian areas. The northern section follows the watershed, the eastern, however, crosses some settlements. Decades of separate development accelerated depopulation and peripherisation of the area. As, due to the policy of separation, the border was extensively fortified (military infrastructure of the Iron Curtain) and well-controlled, cross-border contacts were practically prevented. Although the structure of the areas on both sides of the border is quite similar and both borderlands are peripheric both in their countries, they developed entirely separately. Even after the accession of both countries to the EU and the Schengen area, the features of separation remained preserved. On both sides protected areas perpetuate this isolation.

The Slovenian border with Croatia corresponds to the type of a developing border, due to rapid changes of border regimes and border situations during the last 25 years. The border follows mainly the old administrative boundary between Austrian lands and Hungarian Croatia ${ }^{2}$ shaped from the $16^{\text {th }}$ to the $18^{\text {th }}$ century (ČEPIČ \& Sluga 1979, pp. 189-196). Due to relatively closely related languages and the same (Catholic) cultural provenience, there were many contacts between both sides as well as many mixed marriages. Towards the end of the $18^{\text {th }}$ century, cadastre measurement began. In the region of Žumberak [Gorjanci/Žumberačka gora] the border was drawn around possessions resulting in a 'meandering' line and some enclaves (or exclaves)

2 The perception, that political borders between Yugoslav federal units (republics) had 'only' administrative character is completely wrong. The Yugsolav federal repuplics had extended selfgoverning competences and were, first of all, political entities and structured like countries. They were just not secured by army, police and customs. 
(see CELAR 2002, p. 103), also because of privileged settlers, the "frontiermen" or Uskoki. ${ }^{3}$

Once the dual Monarchy was formed according to the Austro-Hungarian Compromise (1867), the introduction of customs control between Hungarian and Austrian lands saw the partial harmonisation and straightening of the border, the ancestor of today's 'cadastre' border, which later, in the Yugoslav era, underwent several redrawings. They are the reason of most of the disputed cases along the current Slovenian-Croatian border. The border on the Mura River was drawn inside the same cadastral measurement (in the Hungarian part of the dual Monarchy), so that differences emerged only later during the Yugoslav period.

In the section on Istria, the border is entirely new and was shaped according to agreements after World War II. This part is still subject of dispute due to a series of unclear items in the border-drawing process itself (KRISTEN 2006, pp. 24-35). Apart from that, Istria was long ruled by the Republic of Venice and has therefore a Venetian juridical tradition. Austrian authorities just adopted them after conquering the area in the $18^{\text {th }}$ century (ČEPIČ \& Sluga 1979, p. 234).

Another kind of border issues stems from erosion and accumulation processes by the rivers Drava, Mura and Sotla, which changed configuration of and access to property. The third source of issues is infrastructure, especially traffic-related, since it crosses the border several times and there is no clear division of competences regarding maintenance and control. A series of open questions relates to energy facilities (hydroelectric power plants, nuclear power plant Krško) directly at the border or close to it. The fourth group of problems includes interventions, which emerged after the establishment of the countries.

All these circumstances led to a considerable dynamic of the border cultural landscape.

\section{Minorities as impact factors in borderlands}

Minorities result from demarcation processes due to various reasons. Borders were primarily drawn according to the interests of the large powers and for strategic goals. This intention was combined with the expectation that minorities will after some time assimilate to the majority. But this did not always work and minorities are the reality of borderlands up to the present day. Today, a policy in favour of minorities is considered reflecting political wisdom and humanistic principles, but not always easy to be realised. The areas examined are typical heirs of European nationalisms that

3 Uskoki - people of mainly Serbian ethnic origin, who were refugees from areas under Ottoman rule and settled the frontier of the Habsburg Empire. They had special competences and rights in compensation of military border service. 
considered minorities as alien, suspicious elements to be assimilated. The result was an indisposed, cautious and often even aggressive attitude towards minorities and their settlement areas.

According to Italian official estimations, in Italy live close to 52,000 Slovenes, while Slovenian authors estimate by linguistic criteria a population between 80,000 and more than 100,000. In Austria, the last census in 2001 ${ }^{4}$ counted around 13,000 Slovene speakers in Carinthia [Kärnten], but estimations rise up to 45,000. In Hungary, there are close to 3,000 Slovenes and in Croatia 17,000 by the census in 2002, while just a decade earlier there were more than 25,000 . The Slovenian community in Croatia is in the first line a dispersed urban diaspora and just to a smaller part a real territorial minority.

Otherwise, in Slovenia there are around 3,000 Italians and close to 10,000 Hungarians by estimations, while the official number is pretty smaller. Moreover, there are about 10,000 Roma and a relatively strong Serbian (around 60,000), Croatian (43,000) and Bosniak $(40,000)$ diaspora (ZuPANČIČ 2004, pp. 87, 89). Before World War II, the strongest ethnic minority were the Germans - according to some estimations around 45,000 or even more (ZUPANČIČ 2004, p. 88).

Motherlands considered their minorities sometimes as demographic, cultural and frequently also political potentials deriving from their existence occasionally territorial claims. Thus, often a patronising and ethno-centralistic policy was executed. Minorities were instrumentalised for bilateral relations, convenient to occasionally raise an 'issue' or to 'sacrifice' them for the higher interests of bilateral relations.

However, minorities are also a factor in themselves. Due to their competences to cope with at least two languages, cultures, customs, traditions and in particular by the existence of social networks, which evolved across controlled political borders, members of minority groups provide particular services. Minorities and their social and spatial functions were directly and indirectly affected by certain policies related to border and border areas. Support for minorities either by the country of residence or the motherland proved to be a valuable investment in terms of improved international relations. Minorities can play an economically and culturally unifying role in various fields and are an important development factor.

\section{Recent border-landscape changes}

A comparison of critical points in time (1949, 1978, 1990 and 2004) outlines periods of modern European economic and political history strongly reflected in

$4 \quad$ The next census of 2011 does not document language use anymore. 
borderlands and minority policies. A nationalist Europe has evolved through almost half a century of geopolitical polarisation towards the current integration phase.

The decade after World War II was characterised by the beginning of geopolitical polarisation and the creation of the concept of closed borders. In the Gorica region, as an act of defiance, a parallel regional centre was established, directly at the border with the street system facing the 'old' Gorizia as if it was a single location. At the peak of geopolitical competition, a border became a cut-off point. The term Iron Curtain developed as a concept of a heavily secured cumbersome border. In our case, the concept did not persist for long, except at the border with Hungary. After the Cominform resolution of 1949 there was a deterioration of relations between Yugoslavia and the Soviet Union and its political satellites. Consequently, the border with Hungary was hermetically closed. It became a real Iron Curtain with two rarely frequented border crossings, and border traffic even declined after the Soviet intervention in Hungary in 1956. The border with Austria was also heavily controlled since it was legally and politically reconstructed only by the Austrian State Treaty of 1955.

In the 1970s, the border regimes experienced major changes. According to the Yugoslavian Constitution of 1974, the republics of former Yugoslavia had extended autonomy, which enabled Slovenia to focus primarily on the markets of the European Economic Community (EEC). Border regimes were liberalised, the frequency of transitions increased. Italy and Austria were among Slovenia's most important partners. As a result, there was a strong increase in cross-border traffic of goods. The Treaty of Osimo in 1975 enabled the concept of open borders. Only in the Gorica region were 28 crossings of different ranks or one per $2.3 \mathrm{~km}$, which means an exceptional density at a global scale! With the active participation of the Slovenian minority in Italy, crossborder activity rapidly increased, in particular in the fields of education, agriculture and trade as well as providing services to companies. Investment and innovation entered the border area. In contrast to industry, a tertiary paradigm of economic development evolved. The Gorica region became an elite winemaking, culinary, tourism and gambling region, although Slovenia was then at the culmination point of the agrarianindustrial paradigm of development. In contrast, the eastern borderlands at the border with Hungary, the Prekmurje region, stagnated along the closed Iron Curtain and minorities were isolated from their motherlands.

Ten years later, Slovenian borderlands experienced a series of changes due to the dissolution of the political blocs, the collapse of Yugoslavia and the creation of new borders. Due to the economic and political crisis and a lack of resources, the Slovenian borderlands to Italy and Austria specialised in shopping tourism of exceptional character. Minorities assumed therein a very important role because of their language skills, which also contributed to their affirmation. A decisive turning point occurred at the border with Hungary. The Iron Curtain was abandoned and cross-border relations began to develop. But progress was limited since there were no traditions and capacities available. Thus, this border remained at least at the beginning rather passive. 
Today, a completely different picture can be observed. After joining the EU and the Schengen regime there were provisional borders in place. The political climate had improved and cross-border co-operation became a political imperative of local and regional elites. Minorities were recognised as mediators of cross-border communication. In the Gorica region, incentives for cross-border co-operation were not at all necessary, since there existed a wealth of various contacts. Gorica and Nova Gorica developed elements of common urban policies. As regards the borderland to Austria, Slovenian employment in Austria and common projects increased in numbers. The borderland to Hungary remained, however, largely passive with a strong need for incentives and assistance. Regional development was based primarily on motherland interventionism. A perception of 'protection' of the border area was preserved: the role of the Iron Curtain and the area dotted with bunkers was perpetuated by the logic of large-scale protected areas.

Finally, what happened along the Slovenian-Croatian border since both countries became independent? Briefly: markation and demonstration first, followed by internal and international pressure to secure and symbolise, then quick attempts to economise and distinct attempts to close the border area to avoid possible confrontation in the North and intensive border urbanisation as well as parkisation, all close together in the southern, coastal space.

The most obvious sign of a border is its symbolic marking and institutionalised control. At road and railroad crossings, border infrastructure was set up of various ranks as regards presence of police, customs and sanitary control. Many local paths and roads were closed or allowed to be passed only limited and conditionally. The securing of the borderline triggered the formation of two types of zones in the border area: intensification zones along the traffic corridors and peripherisation zones in the areas with less traffic. In the case of the Slovenian-Croatian border, the investment pressure in the first type of areas increased after the end of the Balkan conflicts in 1995; then, traffic increased rapidly. This was followed by a tertiarisation of the borderland, which replaced the older industrial-agricultural paradigm. A new infrastructure was provided to entirely remote areas in the Gorjanci and Kočevje regions. For militarystrategic reasons, several roads were renewed or built ${ }^{5}$ rather quickly, with other forms of technical infrastructure being installed, which was meant to aid the local population and, at the same time, be at the disposal to the security forces in their border control function.

The second significant change is of a mainly symbolic character. Borderlands are important for countries and thus, frequently, if not always, also areas of symbolisation. The border is marked with boards and signs directly at the borderline as well as along roads crossing the border. Gradually, a symbolic aspect can evolve for the elements

\footnotetext{
$5 \quad$ Two completely new local roads were built exclusively for supplying a small military base in the Gorjanci mountains.
} 
of the cultural and historical heritage and natural monuments: all of them speak of 'our' country. These elements are generally also attractive and thus subject to visits. Symbolisation then gradually leads to the expansion of services in borderlands and in the case of the Slovenian-Croatian border of culture, too.

A special variation of symbolisation is the establishment and maintenance of parks, understood as a strategy to protect borderlands, specifically in the phase of control removal. Protection of the borderland with various elements of natural and cultural heritage makes sense at first sight, as it neatly complements the visibility of the local environment and contributes to its touristic validisation. However, protection is also a form of new, indirect control over the borderland, in exchange of which some other development perspectives are abandoned and control is increased. State care and tutorship is highly increased, with the main motive of conservation and maintaining the borderland as it is. Thus, next to the Mura and Drava rivers, most of the area is under 'Nature 2000' protection, while certain smaller reservations have an even stricter regime. Along the Sotla River, there is the Kozjansko park, Jovsi, and the upper Sotla River area, the design of which, however, goes back to the 1980s, similar to the Gorjanci, the Kolpa River area and Snežnik. More than two thirds of the borderland are under a certain kind of protection regime. Doubtlessly the most interesting habitat of all are the saltpans of Sečovlje, the maritime part of which continues into the shallow and actually sensitive area of the Northern Adriatic, the Piran Bay. But this area has, due to its border position and two decades of a border dispute, developed in an entirely different way: towards symbolisation. Both countries, in their rush to prove the ownership of this sea area, attempted to prove the 'Slovenianness' or 'Croatianness' of the Piran Bay. While Slovenia declared this area protected, Croatia applied another name to it (Savudrijska vala) (see KLADNIK, PIPAN \& GAŠPERŠıč 2014, pp. 12-26), developed mariculture (by far the most intense in the entire Northern Adriatic), developed tourism (two casinos directly at the border and according to Slovenian convictions already in the area of protected nature) and let construction works start in areas, which have previously been entirely vacant (Cape Savudrija [Rt Savudrija]) with exclusive villas and apartment houses (ZuPANČIČ \& PIPAN 2012, pp. 28-29).

The third element of change in the borderland is the abandonment of any use. This occurs especially in the 'mature' phase and later, when the range of border infrastructure is not anymore necessary. To avoid disputes in a time, when the border is subject of international arbitration, the use of, e.g., border sand quarries on the Mura and Drava Rivers were abandoned. But this occurred also to flood-preventing embankments or agricultural use. Also the exploitation of sand, rubble and lignite deposits near the Mura River has nearly ceased. To maintain energy supply, many compromises had to be made. The same happened to the railway along Sotla River.

After Croatia's access to the EU, border infrastructure is reduced and will gradually be completely abandoned. 


\section{Conclusion}

Under the conditions of European integration, globalisation, information spread and accompanying processes, mobility significantly increases. Despite small in number, ethnic minorities have significantly contributed to an increase in crossborder co-operation in various fields. Due to their changing role and power, the a priori protection of minorities by motherlands is expected to be replaced by a functional one. A comparative analysis of Slovenia's four border areas indicates the persistence of spatial structures.

Slovenian borderlands reflect a long and rich history, when influences from external centres were dominant: Austrian, Venetian, later Italian, Hungarian (with a strong Soviet impact during the Socialist period) and, of course, Yugoslavian. Minorities in border areas constituted important factors, sometimes understood as 'bridge-makers', but at times also as disturbing and dangerous. Borders and border areas are places of contact as well as of confrontation, of memories as well as of power demonstration and violence. Recently, they turned into places of co-operation, stimulated by the new European spirit. Twin cities at both sides of a border tend to co-operate, but are still far away from common management. They remain spaces of divided interests, local and external.

\section{References}

Bufon M. (2004), Slovenia as a European contact area. In: OrožEn AdAMIČ M. (ed.), Slovenia: a geographic overview, pp. 21-26. Ljubljana, ZRC Založba.

Celar B. (2002), Slovenija in njene meje. Ljubljana, Visoka policijsko-varnostna šola.

ČEPIČ Zd., Sluga M. (eds.) (1979), Zgodovina Slovencev. Ljubljana, Cankarjeva založba.

Fridl J., Kladnik D., OrožEn Adamič M., Perko D., Zupančič J. (eds.), National Atlas of Slovenia. Ljubljana, Rokus Publishing House.

Kladnik D., PIPAN P., GaŠPerŠIČ P. (2014), Poimenovanja Piranskega zaliva. Ljubljana, Založba ZRC SAZU.

KLEMENČıČ V. (1987), Državna meja na območju SR Slovenije in obmejna območja kot geografski fenomen. In: Razprave in gradivo/Treatises and documents, 20, pp. 57-81.

KRISTEN S. (2006), Meje in misije. Dileme slovensko-hrvaške razmejitve v Istri v vojaškem, političnem, diplomatskem in obveščevalnem primežu II. svetovne vojne. Ljubljana, Založba 2000.

Moritsch A. (1999), Ursachen und Folgen der politischen Teilung in den Alpen - das Beispiel Dreiländereck. In: Dela, 13, pp. 189-200.

ZAJC M. (2006), Kje se slovensko neha in hrvaško začne. Slovensko-hrvaška meja v 19. in na začetku 20. stoletja. Ljubljana, Modrijan. 
ZupANČIČ J. (1999a), Karavanke - od ločnice do povezovališča Slovencev z obeh strani meje. In: Dela, 13, pp. 337-348.

Zupančič J. (1999b), Slovenci v Avstriji/Slovenes in Austria (= Geographica Slovenica, 32). Ljubljana, Institute of Geography.

Zupančič J. (2002), Grenzüberschreitende Pendelwanderung aus Slowenien nach Österreich und Italien. In: Mitteilungen der Österreichischen Geographischen Gesellschaft, 144, pp. 145157.

ZUPANČIČ J. (2004), Ethnic structure of Slovenia and Slovenes in neighbouring countries. In: OrožEn AdAmiČ M. (ed.), Slovenia: a geographic overview, pp. 87-92. Ljubljana, ZRC Založba.

ZuPANČıČ J. (2008), Značaj in funkcije političnih meja v Evropi. In: Ars \& humanitas, 2, 1, pp. 82-96.

ZuPANČIČ J., PIPAN P. (2012), Slovensko morje in obala: Severni Jadran v geopolitični perspektivi ter problemi razmejevanja med Italijo, Slovenijo in Hrvaško. In: OGRIN D. (ed.), Geografija stika Slovenske Istre in Tržaškega zaliva, pp. 13-35. Ljubljana, Znanstvena založba Filozofske fakultete. 